\title{
Integrating industrial and financial analysis into a rating methodology for corporate risk detection: the case of the Vicenza manufacturing firms.
}

Guido Max Mantovani, Giancarlo Coro, Paolo Gurisatti and Mattia Mestroni

\begin{abstract}
Banks weakness derived from rating models that produce cyclical effects on credit availability and are not able to anticipate anti-cyclical firms' trends. The aim of the paper is to develop a framework for an original rating methodology derived from integration of industrial and financial analysis able to identify best performers in crisis scenarios (anti-cyclically). Industrial analysis is based on firm heterogeneity approaches to measure three dimensions of analysis: innovation, internationalization and growth. Financial analysis focuses on operational return and risks measures and develops an integrated classification of firms using standardized XBRL financial data. Further integration of the two methodologies is used to create the effective set of information needed for rating system.
\end{abstract}

Keywords: Corporate risks, Rating, Firm behavior, Firm performance

\section{Introduction}

Techniques adopted in the classical financial risk approaches are often useless, since they are based on the heterogeneous nature of risks. Instead, in real terms corpo-

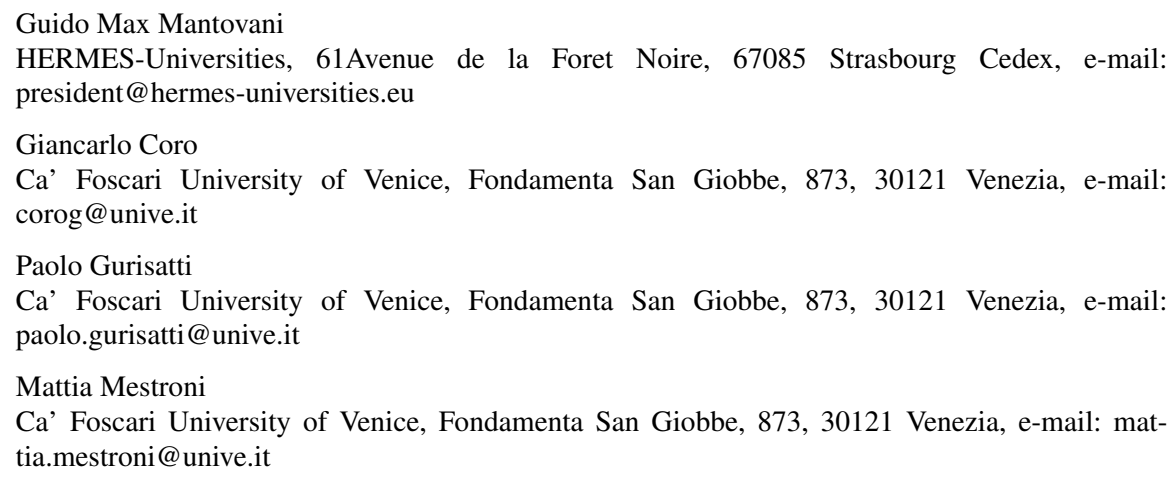


rate risks have huge endogenous components. Risk is continuously crafted by managerial decisions, including those adopted in order to manage them. The simple financial approach in corporate risk management is reductive, missing the business model determinants along with the managerial decisions contribution. An integrated approach is then required, in order to soundly support the managerial choices.

\section{Literature review}

The great financial crisis of 2008 has shown all the weaknesses of a World Bank regulation that presents high levels of pro-cyclical effects. The evidence of such limits and threats incorporated in Basel regulation was extensively proved by academic

world [5][8]. The high proportion of SMEs and the high productivity of North East [1][7] drive our choices on manufacturing firms of Vicenza to test our original rating methodology. The integration of financial methodology with an industrial one puts our work in line with some precedent papers that underline the importance of adding soft information to standard financial approaches to a correct valuation of firms credit merit [6].

\section{Industrial analysis}

This investigation was initiated with a survey to a sample of 309 industrial firms, selected by industry and size representativeness, located in Vicenza. Our research hypothesis refers to firm heterogeneity approaches [2]: firstly we look at innovation capabilities, collecting data on patents and R\&D offices; secondly, we evaluate the international activities through information on firm's export, the occurrence of affiliates abroad and where firms' main competitors are; finally, we measured the turnover and profit performance just after the 2008 crisis. According with the emerging characteristics, we named the five groups as following:

- G1 - International and reactive firm (about 20 per cent of the sample);

- G2 - International but not reactive firm (15 per cent of the sample);

- G3 - Local reactive firm (20 per cent of the sample);

- G4 - National or local not reactive firms (15 per cent of the sample);

- G5 - Average or standard firms (30 per cent of the sample).

\section{The sample}

Any authority identification code of the 309 firms considered in industrial analysis was available in our data set of manufacturing firms located in Vicenza . Using identification codes, by AIDA database research function we could extract complete 
balance sheets for financial analysis implementation. The analysis was performed on a sample data containing continuous and complete 2004-2012 standard financial reports.

\section{Financial analysis}

The intuition behind this model is the need to give an appropriate emphasis to risk dimensions in classifying a "performing" firm. The resulting matrix (Table 1) classifies the sample into six quadrants: "OK firms", "KO firms", two quadrants identified as "Critic Firms" and two quadrants identified as "Anomalous Firms to be reclassified." Three risk dimensions considered are Degree of Operative Leverage (DOL)

Table 1 Financial model framework for the classification of firms $(\mathrm{ROC}=$ Return On Capital)

\begin{tabular}{|c|c|c|c|c|}
\hline & & \multirow{2}{*}{\multicolumn{3}{|c|}{ RETURNS }} \\
\hline & & & & \\
\hline & & \multicolumn{2}{|c|}{ INCREASING ROC $\left(R O C_{2010}>R O C_{2007}\right)$} & \multirow{2}{*}{$\frac{\mid \begin{array}{l}\text { DECREASING ROC } \\
\left(R_{O} O C_{2010}<R O C_{2007}\right)\end{array}}{\mid \text { WORSENING }}$} \\
\hline & & $\left|\begin{array}{l}\text { STEADY } \quad \text { TREND } \\
\left(R O C_{2010}>R O C_{2008}\right)\end{array}\right|$ & $\left|\begin{array}{l}\text { UNSTEADY TREND } \\
\left(R O C_{2010}<R O C_{2008}\right)\end{array}\right|$ & \\
\hline \multirow[t]{2}{*}{ RISK } & $\begin{array}{l}\text { DECREASING } \\
\text { RISK }\end{array}$ & OK & $\begin{array}{l}\text { Anomalous Firms to be } \\
\text { reclassified }\end{array}$ & Critic firms \\
\hline & $\begin{array}{l}\text { INCREASING } \\
\text { RISK }\end{array}$ & $\mid \begin{array}{l}\text { Anomalous Firms to be } \\
\text { reclassified }\end{array}$ & Critic firms & $\mathrm{KO}$ \\
\hline
\end{tabular}

for both price and volumes changes in operating revenue, and working capital absolute intensity, that is the working capital on operating revenue rate. Risk indexes and ROC definitions follow previous research standards defined by Mantovani et al [9]. The above analysis is performed over three timeframes: the pre-crisis period (2004-2007); the crisis period (2007-2010) and the post-crisis period (2010-2012).

\section{Results}

In sum, we can say that industrial analysis produce a consistent method to identify best performers, confirmed by post crisis financial analysis. On one hand, the industrial method identifies firms with high return rate and low risk exposure - as G1, G3 and G5- and firms with low return rate and high risk exposure - as G2 and G4. On the other, the financial method confirm the capacity to react to crisis of best performers groups, identified by industrial methodology - G1 and G3 - and the expectations about cluster performance are confirmed also after crisis. 


\section{Conclusions}

Financial analysis demonstrate that industrial classification identifies correctly the cluster G1 as best performers: it has the best capacity to react to crisis and the high percentage of $\mathrm{OK}$ firms during the pre-crisis, the crisis and the post-crisis periods. Also G4 was correctly identified as the worst performer group: it has the lowest percentage of improving firms and the highest percentage of worsening firms in crisis and post crisis timeframes. As industrial model predicts, G3 and G5 result as clusters of good performers even if due to different features. The most interesting cluster is the G2 group, defined by the industrial analysis as a group of international players firms with low performance. During crisis, this group suffers a high degree of risk exposure that is the reason of the low performance on the three timeframes. But, its international openness permitted to reduce risk exposure after crisis and G2 report an improvement in financial classification, even if conserving low ROC levels. The results of the empirical analysis are clear: an integrated approach in corporate risk detection is clearly more efficient. By adopting such a methodology you must measure the impact of risks that do persist into the firm, along with their impact as a bundle.

\section{References}

[1] Bank of Italy: The economy of the North East. Workshops and Conferences, (2011)

[2] Bernard, A.B., Redding, S.J., Schott, P.K. The Empirics of Firm Heterogeneity and International Trade, Annual Review of Economics, (2012)

[3] Blundell-Wignall, A., Atkinson, P. Thinking beyond Basel III: necessary solutions for capital and liquidity, OECD journal: financial market trends - volume 2010/1, (2010)

[4] Dainelli, F., Giunta, F., Cipollini, F.: Determinants of SME credit worthiness under Basel rules: the value of credit history information. PSL Quarterly Review, vol. 66 n. 264 21-47, (2013)

[5] Kashyap, S. Cyclical implications of the Basel-II capital standards, University of Chicago, working paper , (2003)

[6] Liberti, J.M.: How does organizational form matter? Distance, communication and soft information. mimeo (2005)

[7] Manfra, P.: Entrepreneurship, firm size and the structure of the Italian economy. Journal of Entrepreneurial Finance, pages 99-111, (2002)

[8] Mantovani, G. M., Daniotti E.: Valori e Capitali per un Nuovo Patto di Sviluppo del Sistema: il caso Treviso. Ca Foscari editions Digital Publishing, (2012)

[9] Mantovani, G.M., Daniotti, E., Gurisatti, P. In Search of Corporate Risk Measures to Complete Financial Reporting. The Case of the "Caldarerie" industry, International Research Journal of Applied Finance, Vol. 4 Issue 3, p458-489 (2013)

[10] Sironi, A., Zazzara, C.: The New Basel Accord: Implications for Italian Banks. Review of Financial Economics, vol. 12, pages 99-126, (2003) 
Dipartimento di Scienze Economiche e Statistiche

Università degli Studi di Salerno

Campus universitario di Fisciano, February 14th 2014

\section{Certification}

We certify that the chapter "Integrating industrial and financial analysis into a rating methodology for corporate risk detection: the case of the Vicenza manufacturing firms" by Guido Max Mantovani, Giancarlo Coro, Paolo Gurisatti and Mattia Mestroni.

has been accepted for publication in the book "Mathematical and Statistical Methods for Actuarial Sciences and Finance" (edited by Cira Perna and Marilena Sibillo) published by Springer, April 2014, with ISBN 978-3-319-05013-3.

The Editors

Cira Perna and Marilena Sibillo 
